\title{
ANALISIS PRESUPOSISI PADA PERCAKAPAN \\ SISWAKELAS XI JURUSAN TATA BUSANA \\ SMK NEGERI 3 LANGSA \\ TAHUN 2019
}

\author{
Torang Siregar ${ }^{1}$, Joko Hariadi, Desy Irafadillah Effendi, Soedirman Z \\ ${ }^{1}$ Mahasiswa Program Studi Bahasa Indonesia, FKIP Universitas Samudra \\ ${ }^{1}$ torangtorang1212@gmail.com
}

Info Artikel :

Diterima:

Disetujui:

Dipublikasikan:
Abstrack

The purpose of this study is to describe the analysis of presuppositions in conversations in conversations of class XI students in fashion department of SMK Negeri 3 Langsa in 2019. The benefits of this study are expected to contribute to the development of Pragmatics related to presupposition. The method in this study uses a descriptive method with a qualitative approach. The data source in this study was conversation or class XI students majoring in fashion at SMK Negeri 3 Langsa in 2019. As for the data obtained there were 28 data consisting of 3 potential presupposition data, 10 active presupposition data, 3 lexical presupposition data, 3 non-active presupposition data, 8 structural data, and 1 counterfactual data.

Keywords: Pragmatics, Presuppositions, Students

\section{Abstrak}

Tujuan penelitian ini adalah mendeskripsikan analisis presuposisi pada percakapan pada percakapan siswa kelas XI jurusan tata busana SMK Negeri 3 Langsa tahun 2019. Manfaat dari penelitian ini diharapkan dapat memberikan kontribusi dalam perkembangan ilmu Pragmatik yang berkaitan dengan presuposisi. Metode dalam penelitian ini menggunakan metode deskriptif dengan pendekatan kualitatif. Sumber data dalam penelitian ini adalah percakapan atau siswa kelas XI jurusan tata busana SMK Negeri 3 Langsa tahun 2019. Adapun data diperoleh terdapat 28 data yang terdiridari 3 data presuposisi potensial, 10 data presuposisi faktif, 3 data presuposisi leksikal, 3 data presuposisi nonfaktif, 8 data struktural, dan 1 data konterfaktual.

Kata Kunci :Pragmatik, Presuposisi, Siswa 


\section{Pendahuluan}

Bahasa adalah suatu sistem ujar atau alat komunikasi yang digunakan oleh seseorang dalam berkomunikasi oleh individu maupun kelompok tertentu. Bahasa merupakan mekanisme tanda vokal yang arbirter, digunakan oleh suatu kelompok warga negara buat berpartisipasi, kolerasi serta mengenali diri (KBBI, 2008:116). Saat suatu komunikasi, bermanfaat secara lisan maupun tulisan pasti ada suatu topik yang dibicarakan antara satu dan lainnya dalam mengemukakan pikiran, pendapat, serta kerjasama. Baisu (2015:129) menyatakan bahwa tutur kata menjadi suatu perantara buat berkomunikasi wajib transparan maksudnya, arahnya, lalu sasaran hendaknya berita yang disampaikan untuk lawan ujar dapat dimengerti.

Menurut Gawen (2017:1) bahasa adalah suatu rekayasa teknologi untuk mengemas pengetahuan yang tertangkap manah (mind) untuk menghimpun, menyebarkan, dan mewariskan pengetahuan. Bahasa yang kita gunakan sehari-hari dalam setiap percakapan memiliki ragam bahasa dari tindak tutur dan mitra tutur dalam interaksi sosial.

Yule (2006:3) pragmatik merupakan analisis terhadap tujuan pengujar. Selain Yule, Rohmadi (dalam Rohmadi, 2014:54) juga berpendapat bahwa tinjauan pragmatik tidak bisa terhindar dari situasi pengujar. Secara terperinci, pragmatik adalah suatu percakapan yang berhubungan dengan makna tuturan yang disampaikan oleh penutur (penulis) dengan mempertimbangkan situasi dan kontekstual.

Analisis pragmatik merupakan analisis yang berhubungan dengan suatu percakapan penutur dan tuturan. Ismari ( dalam Yuniarti, 2014:229-230) Bahasa maupun kalimat merupakan salah satu referensi kondisi kalimat yang sebagai ujaran. Aturan perlu perbincangan dapat dibedakan menjadi aturanaturan oleh jenis-jenis kejadian kata yang beda, contohnya, diskusi, ceramah argumen, debat, pengadilan di luar sidang, wawancara, upacara keagamaan, dan rapat. Jadi, percakapan adalah suatu pembicaraan yang terlebih dahulu memikirkan apa yang hendak disampaikan kepada lawan bicara.

Menurut Grice (dalam Suaedi, 2018:64) ujaran akan memfokuskan dengan adanya orientasi umsurunsur negosasi aktivitas yang semula berbeda pada susunan kata-kata (1) menyelaraskan aspek-aspek dalam waktu sebentar, (2) memadukan suatu jalinan kerja sama dengan begitu penutur dan mitra tutur sama-sama memerlukan dalam mengharmoniskan suatu kalimat, dan (3) Kemudian mengusahakan terdapat tergabung dengan pola komunikasi secara langsung maupun tidak langsung. Jika adanya kerjasama dalam berkomunikasi maka akan terjalin komunikasi yang baik antara penutur dan lawan tutur. Dalam sebuah percakapan sebenanrnya seorang penutur tidak menyadari telah menggunakan presuposisi sebelum penutur hendak bicara.

presuposisi merupakan sesuatu yang telah diasumsikan oleh penutur, adanya peristiwa sebelum suatu tuturan (Yule, 2006:43). Cummings (dalam Baisu, 2015:133) menyatakan bahwa praanggapan atau presuposisi adalah asumsi-asumsi atau inferensiinferensi yang tersirat dalam ungkapan-ungkapan linguistik tertentu. Sejalan dengan definisi dari Yule dan Cummings dapat disimpulkan bahwa presuposisi adalah suatu tuturan yang memiliki maksud atau makna yang tersirat didalam ungkapan dan memiliki dugaan sebelum mengutarakan percakapan.

Presuposisi potensial merupakan suatu tuturan presuposisi yang memberitahukan suatu keberadaan seseorang secara jelas sesuai dengan yang terjadi. Presuposisi faktif merupakan presuposisi yang menginformasikan suatu peristiwa atau kegiatan mengikuti kata kerja yang dianggap suatu kejadian nyata sedang dilakukan. Presuposisi leksikal merupakan prsuposisi sebagai bentuk suatu makna yang dinyatakan formal di asumsikan suatu petutur yang tidak dinyakatan dapat dipahami.

Kemudian Presuposisi nonfaktif merupakan suatu kebalikan dari faktif yang menyatakan kejadian yang diasumsikan sedang tidak terjadi atau sama sekali benar. Presuposisi Struktural merupakan presuposisi kalimat-kalimat yang mengancu pada unsur ataupun bentuk tertentu yang dianalisis secara utuh dan formal yang mengikuti juga kata kerja dan tanta tanya. Selanjutnya, presuposisi konterfaktual merupakan presuposisi yang tidak benar sedang terjadi melaikankan merupakan suatu kebalikan yang merupakan suatu khayalan atau angan-angan yang bertolak belakang dengan kenyataan.

Penelitian serupa telah pernah dilakukan oleh Armian dan Meilestari (2018) yaitu Presuposisi dalam Novel Mendayung Impian Karya Reyhan M. Abdurrohman. Hasil yang didapatkan dari penelitiannya adalah presuposisi potensial, faktif, leksikal, nonfaktif, struktural, dan konterfaktual. Pada setiap presuposisi yang diteliti ditemukan ditandai frasa nominal, frasa adjektiva, frasa adjectival, keterangan tempat, keterangan waktu, ungkapan khusus, konjungsi dan tanda tanya. yang ditemukan berupa presuposisi yang ditandai oleh konjungsi yang menyatakan pengandaian.

Selain Armian dan Meilestari, Baisu (2015) meneliti tentang Analisis Praanggapan Tindak Tutur dalam Persidangan di Kantor Pengadilan Negeri Kota Palu. Hasil yang didapatkan dari penelitiannya adalah presuposisi potensial, faktif, leksikal, nonfaktif, struktural, dan konterfaktual. Diikuti dengan fungsi tindak tutur lokusi, tindak lokusi, dan tindak tutur perlukosi. Kemudian diikuti oleh Putri (2015) meneliti tentang Praanggapan pada Implikatur Percakapan Dalam Serial Kuroko No Basuke Season 
1 Karya Tadatoshi Fujimaki Hasil yang didapatakan dari penelitiannya adalah 33 data yang terdiri dari praanggapan eksistensi dan praanggapan faktual.

Penelitian ini didasarkan beberapa alasan yaitu, Jurusan tata busana SMK Negeri 3 Langsa tahun 2019 dijadikan objek penelitian karena siswanya lebih aktif dalam berbicara sehingga peneliti lebih mudah untuk memperoleh data. Penelitian ini belum pernah diteliti sebelumnya.

\section{Metode Penelitian}

Penelitian analisis presuposisi pada percakapan siswa kelas XI jurusan tata busana SMK Negeri 3 Langsa tahun 2019 ini menggunakan metode deskriptif dengan pendekatan kualitatif. Metode kualitatif yang disebut juga dengan metode penelitian naturalistik karena penelitiannya dilakukan pada kondisi yang alamiah (natural setting); disebut juga sebagai metode deskripsi, karena pada awalnya metode ini banyak digunakan untuk penelitian bidang antropologi budaya; disebut sebagai metode kualitatif, karena data yang terkumpul dan analisisnya lebih bersifat kualitatif Sugiyono (2017:8).

Metode deskriptif kualitatif dianggap tepat pada penelitian ini, karena mengungkapkan keadaan yang sedang berlangsung. Penelitian ini, digunakan untuk memudahkan peneliti menemukan percakapanpercakapan presuposisi pada percakapan yang terjadi di kelas XI Jurusan Tata Busana SMK Negeri 3 Langsa tahun 2019. Penelitian ini juga, mendeskripsikan bahasa pada percakapan siswa kelas XI Jurusan Tata Busana SMK Negeri 3 Langsa tahun 2019 sesuai dengan presuposisi potensial, faktif, leksikal, nonfaktif, struktural, dan konterfaktual. Secara kualitatif, penelitian ini menghasilkan data deskriptif dengan menggunakan kata-kata yang diamati.

Dalam penelitian sumber data yang diterima adalah sebagai subjek dari mana data diperoleh (Arikunto, 2013:172). Jadi, sumber data yang digunakan pada penelitian ini adalah Siswa dan Guru Kelas XI Jurusan Tata Busana SMK Negeri 3 Langsa tahun 2019. Data yang diambil berupa tuturan atau percakapan yang berbentuk presuposisi Siswa dan Guru Kelas XI Jurusan Tata Busana SMK Negeri 3 Langsa tahun 2019.

Dari peneliti berpengalaman diperoleh yakni suatu petunjuk bahwasannya mencatat data yang telah diobservasi bukanlah sekedar mencatat, akan tetapi juga mengadakan suatu pertimbangan kemudian mengadakan penilaian kedalam suatu bertingkat yang membuat sata menjadi jelas Arikunto (2006:229). Dalam hal ini, teknik yang digunakan adalah mengamati dan mencatat. Teknik mengamati dilakukan dengan mengamati sasaran penelitian, yaitu presuposisi pada percakapan siswa kelas XI Jurusan Tata Busana SMK Negeri 3 Langsa tahun
2019 yakni, (a) mengamati dan mengumpulkan data menggunakan media alat perekam ( handphone dan tape recorder) isi keseluruhan dari awal pembicaraan hingga akhir dengan tujuan mengindentifikasi sudut pembicaraan secara umum, (b) melakukan pengamatan dilakukan pencatatan data yang mengandung presuposisi pada percakapan siswa kelas XI Jurusan Tata Busana SMK Negeri 3 Langsa tahun 2019 tersebut.

Pada penelitian ini yang digunakan adalah teknik analisis bentuk kualitatif. Teknik analisis data yang digunakan sudah jelas dan fakta mengikuti kaidah-kaidah penelitian, yaitu suatu topik atau objek diarahkan untuk menjawab rumusan masalah yang ditemukan. Dalam penelitian kualitatif data diperoleh dari berbagai sumber baik individu atau kelompak suatu tempat yang ditelah dipilih, dengan teknik pengumpulan data yang berbagai macam(Sugiyono, 2017:243).

\section{Hasil dan Pembahasan}

Penelitian ini merupakan penelitian yang difokuskan pada tuturan siswa Kelas XI Jurusan Tata Busana SMK Negeri 3 Langsa tahun 2019. Adapun cara yang digunakan peneliti guna mendapatkan data yaitu mengamati komunikasi yang terjadi dilokasi penelitian. Dengan hal ini, peneliti telah mengumpulkan data presuposisi yang telah diperoleh dari Siswa kelas XI Jurusan Tata Busana SMK Negeri 3 Langsa tahun 2019 sebanyak 28 data presuposisi, yakni presuposisi potensial 3 data, presuposisi faktif 10 data, presuposisi leksikal 3 data, presuposisi 3 data, presuposisi struktural 8 data, dan presuposisi konterfaktual 1 data.

Berikut ini adalah data-data presuposisi potensial Siswa kelas XI Jurusan Tata Busana SMK Negeri 3 Langsa tahun 2019

Data I

Waktu : Jumat, 18 Oktober 2019, Pukul 11.58 WIB

Penutur : Siswa Kelas XI

Lokasi : Ruang Kelas SMK Negeri 3 Langsa

Jurusan : Tata Busana

Siswa 1 : "Mana si Risa?"

Siswa 2 : "Itu si Risa"

Pada tuturan tersebut menunjukkan adanya presuposisi jenis potensial dari seorang siswa kepada temannya yang juga seorang siswa. Siswa tersebut memberitahukan keberadaan pribadi yang dinyatakan dengan kata yakni mengatakan itu si Risa, siswa 2 memberi tahu keberadaan si Risa kepada siswa 1 dengan definit. 
Berikut ini adalah data-data presuposisi faktif Siswa kelas XI Jurusan Tata Busana SMK Negeri 3 Langsa tahun 2019.

Data I

Waktu : Rabu, 23 Oktober 2019, Pukul 10.50 WIB

Penutur : Siswa Kelas XI

Lokasi : Ruang Kelas SMK Negeri 3 Langsa

Jurusan : Tata Busana

Guru : "Bingung ya, Ibu bacanya?"

Siswa : "Bingung, Bu".

Pada tuturan tersebut menunjukkan adanya presuposisi jenis faktif dari seorang guru. Guru tersebut memiliki dugaan bahwa siswa tersebut merasa bingung dan dugaan guru tersebut benar bahwa siswa tersebut merasa bingung. Tuturan tersebut sedang membicarakan atau mempelajari tentang cerpen. Adanya satu tuturan tersebut yang menandakan adanya presuposisi, yaitu kata bingung. Penjelasan yang ikut serta tutur bingung bisa dikatakan menjadi fakta. Berdasarkan presuposisi yang mengikuti kata kerja adanya kebenaran, yaitu si penuturnya mengajari siswa tentang cerpen dan siswa kurang mengerti atau bingung dalam menerima pembahasan dari si penutur pada saat jam belajar bahasa Indonesia.

Berikut ini adalah data-data presuposisi leksikal Siswa kelas XI Jurusan Tata Busana SMK Negeri 3 Langsa tahun 2019.

Data I

Waktu : Senin, 21 Oktober 2019, Pukul 09.45 WIB

Penutur : Siswa Kelas XI

Lokasi : Ruang Kelas SMK Negeri 3 Langsa

Jurusan : Tata Busana

\section{Siswa 1 : "Emang netizen itulah!" \\ Siswa 2 : "Aneh foto-foto terakhirnya itu"}

Tuturan tersebut menunjukkan presuposisi leksikal. Siswa 1 mengungkapkan emang netizen itulah dan siswa 2 langsung dapat menandai konteks tuturan tersebut karena siswa 2 sudah ada pengetahuan atau informasi tentang topik yang dibahas siswa 1. Jadi, komunikasi dapat berjalan dengan baik.

Berikut ini adalah data-data presuposisi nonfaktif Siswa kelas XI Jurusan Tata Busana SMK Negeri 3 Langsa tahun 2019.

Data I

Waktu : Senin, 21 Oktober 2019, Pukul 09.45 WIB

Penutur : Siswa Kelas XI

Lokasi : Ruang Kelas SMK Negeri 3 Langsa

Jurusan : Tata Busana

Siswa 1 : "Emang netizen itulah!"

Siswa 2 : "Aneh foto-foto terakhirnya itu"

Siswa 1 : "Tapi sekarang dia sering posting"

Pada tuturan tersebut menunjukkan adanya presuposisi jenis nonfaktif dari seorang siswa kepada temannya. Siswa 2 menyatakan kekesalannya karena melihat unggahan foto di media sosial yang terkesan vulgar. Padahal kenyataannya, belum tentu unggahan foto netizen di media sosial tersebut tidak baik karena siswa 1 belum melihat langsung unggahan tersebut.

Berikut ini adalah data-data presuposisi struktural Siswa kelas XI Jurusan Tata Busana SMK Negeri 3 Langsa tahun 2019.

Data I

Waktu : Senin, 21 Oktober 2019, Pukul 09.45 WIB

Penutur : Siswa Kelas XI

Lokasi : Ruang Kelas SMK Negeri 3 Langsa

Jurusan : Tata Busana

Siswa 1 : "Tapi sekarang dia sering posting"

Siswa 2 : "Ini apa? Kek nampain dadanya gitu”

Siswa 1 : "Karena itulah dia di bully"

Pertanyaan siswa 2 ini apa? Menunjukkan presuposisi struktural karena siswa 2 bertanya tentang unggahan foto salah satu akun instagram yang vugar dimedia sosial kepada temannya, yang disertai dengan bukti.

Berikut ini adalah data-data presuposisi Konterfaktual Siswa kelas XI Jurusan Tata Busana SMK Negeri 3 Langsa tahun 2019.

Data I

Waktu : Jumat, 18 Oktober 2019, Pukul 11.58 WIB

Penutur : Siswa Kelas XI

Lokasi : Ruang Kelas SMK Negeri 3 Langsa

Jurusan : Tata Busana
Siswa 1 : "Sebuah nasi yang ada lauknya! Sebuah kacang kedelai yang dipermentasikan"
Siswa 2 : "Jadinya basi"

Pada tuturan tersebut menunjukkan adanya presuposisi jenis konterfaktual. Siswa 1 menyatakan hayalannya kepada siswa 2 tentang nasi goreng yang 
sedang dimakannya. Dia berhayal nasi tersebut ditambah dengan lauknya kacang kedelai yang dipermentasikan, padahal kenyataannya tidak ada kedelai yang dipermentasikan saat itu.

Simpulan Presuposisi merupakan salah satu kajian pragmatik yang mempelajari tentang percakapan, praanggapan, tuturan, cara seseorang menerima praanggapan secara lisan dan nonlisan

Setelah mengumpulkan, menaklasifikasikan, dan menganalisis data pada tuturan siswa kelas XI jurusan tata busana SMK Negeri 3 Langsa tahun 2019, hasil penelitian ini menunjukkan bahwa terdapat 28 data yang terdiri dari 3 data presuposisi potensial, 10 data presuposisi faktif, 3 data presuposisi leksikal, 3 data presuposisi nonfaktif, 8 data struktural, dan 1 data konterfaktual. Percakapanpercakapan siswa siswa kelas XI Jurusan Tata Busana SMK Negeri 3 Langsa tahun 2019 yang menandakan presuposisi faktif "Bisa buat desain sambil ngaji, pertama ke kamar mandi habis tu ke belakang habis tu ke kamar mandi habis itu ke kantin, habis itu ke parkir" pada data , "Belum siap baju kami, tengok resi bulu matanya lentik, ee pake penjepit, tetapi sekarang dia posting" pada data II, “ uda jam sepuluh ke atas, mana baju merah yang sudah digunting" pada data III, serta Bingung ya Ibu bacanya?" pada data VI.

Dalam menentukan presuposisi, konteks sangat mempengaruhi anggapan yang dimunculkan dari tuturan tersebut. Namun, dalam menentukan presuposisi potensial, faktif, leksikal, nonfaktif, struktural dan konterfaktual, konteks dapat diabaikan dan penentuannya dapat dilihat dari percakapan siswa sehari-hari.

\section{Daftar Rujukan}

Arikunto, Suharsimi. 2006. Prosedur Penelitin Suatu Pendekatan Praktik. Jakarta PT Rineka Cipta.

Arikunto, Suharsimi. 2013. Prosedur Penelitin Suatu Pendekatan Praktik. Jakarta PT Rineka Cipta.

Baisu, Laode. 2015. Praanggapan Tindak Tutur dalam Persidangan Di Kantor Pengadilan Negeri Kota Palu. Jurnal Bahasantodea. Vol. 3 Nomor 2. Halaman 129-143. Pascasarjana Universitas Tadulako.

Gawen, Bala Alexander. 2017. Pembelajaran Pragmatik. Yogyakarta: Penerbit Ombak.

Meilestari, Sela Nova dan Armia. 2018. Presuposisi Dalam Novel Mendayung Impian Karya Reyhan m. Abdurrohman. Jurnal Bahasa dan
Sastra. Vol. 12. Nomor 1. Halaman 88-102. Universitas Syiah Kuala Darussalam.

Pusat Departemen Pendidikan Nasional. 2008. Kamus Besar Bahasa Indonesia. Jakarta: PT Gramedi Pustaka Utama.

Putri Sandi Aries Fitri Eka. 2015. Praanggapan Pada Implikatur Percakapan Dalam Serial Kuroko No Basuke Season 1 Karya Tadatoshi Fujimaki. Jurnal Mahasiswa.Vol. 3. Nomor 2. Halaman 94-99. Universitas Negeri Surabaya.

Rohmadi, Muhammad. 2014. Kajian Pragmatik Percakapan Guru dan Siswa Dalam Pembelajaran Indonesia. Jurnal Fadeogogia. Vol. 17 Nomor 1. Halaman 5361. Universitas Sebelas Maret.

Suaedi, Hasan. 2018. Analisis Percakapan Guru Dan Siswa Dalam Pembelajaran Bahasa Indonesia. Jurnal Bahasantodea. Vol. 3 Nomor 1. Halaman 63-72. Universitas Muhammadiyah Jember.

Sugiyono. 2017. Metode Penelitian Kuantitatif Kualitatif \& RND. Bandung: Alfabeta.

Yule, George. 2016. Pragmatik. Yogyakarta: Pustaka Pelajar Offset.

Yuniarti, Netti. 2014. Implikatur Percakapan Dalam Percakapan Humor. Jurnal Pendidikan Bahasa Indonesia. Vol. 3 Nomor 2. Halaman 225-240. Program Studi Pendidikan Bahasa dan Sastra Indonesia IKIP-PGRI. 